OPEN ACCESS

Edited by:

Antonella Marangoni,

University of Bologna, Italy

Reviewed by:

Barbara Giordani,

University of Bologna, Italy

Olga Budilovskaya,

D. O. Ott Research Institute of

Obstetrics, Gynecology and

Reproductology, Russia

*Correspondence:

Zongxin Ling

lingzongxin@zju.edu.cn

${ }^{\dagger}$ These authors have contributed equally to this work

Specialty section: This article was submitted to Biofilms,

a section of the journal

Frontiers in Cellular and Infection Microbiology

Received: 11 October 2021 Accepted: 04 November 2021 Published: 22 November 2021

Citation:

Zheng N, Guo R, Wang J, Zhou W and

Ling $Z$ (2021) Contribution of

Lactobacillus iners to Vaginal Health and Diseases: A Systematic Review.

Front. Cell. Infect. Microbiol. 11:792787.

doi: 10.3389/fcimb.2021.792787

\section{Contribution of Lactobacillus iners to Vaginal Health and Diseases: A Systematic Review}

\author{
Nengneng Zheng ${ }^{1 \dagger}$, Renyong Guo ${ }^{2 \dagger}$, Jinxi Wang ${ }^{1}$, Wei Zhou ${ }^{1}$ and Zongxin Ling ${ }^{3,4 *}$ \\ ${ }^{1}$ Department of Gynecology and Obstetrics, The First Affiliated Hospital, College of Medicine, Zhejiang University, Hangzhou, \\ China, ${ }^{2}$ Department of Laboratory Medicine, The First Affiliated Hospital, College of Medicine, Zhejiang University, Key \\ Laboratory of Clinical In Vitro Diagnostic Techniques of Zheiliang Province, Hangzhou, China, ${ }^{3}$ Collaborative Innovation \\ Center for Diagnosis and Treatment of Infectious Diseases, State Key Laboratory for Diagnosis and Treatment of Infectious \\ Diseases, National Clinical Research Center for Infectious Diseases, The First Affiliated Hospital, School of Medicine, Zhejiang \\ University, Hangzhou, China, ${ }^{4}$ Institute of Microbe \& Host Health, Linyi University, Linyi, China
}

Lactobacillus iners, first described in 1999, is a prevalent bacterial species of the vaginal microbiome. As L. iners does not easily grow on de Man-Rogosa-Sharpe agar, but can grow anaerobically on blood agar, it has been initially overlooked by traditional culture methods. It was not until the wide application of molecular biology techniques that the function of $L$. iners in the vaginal microbiome was carefully explored. $L$. iners has the smallest genome among known Lactobacilli and it has many probiotic characteristics, but is partly different from other major vaginal Lactobacillus species, such as L. crispatus, in contributing to the maintenance of a healthy vaginal microbiome. It is not only commonly present in the healthy vagina but quite often recovered in high numbers in bacterial vaginosis (BV). Increasing evidence suggests that $L$. iners is a transitional species that colonizes after the vaginal environment is disturbed and offers overall less protection against vaginal dysbiosis and, subsequently, leads to BV, sexually transmitted infections, and adverse pregnancy outcomes. Accordingly, under certain conditions, $L$. iners is a genuine vaginal symbiont, but it also seems to be an opportunistic pathogen. Further studies are necessary to identify the exact role of this intriguing species in vaginal health and diseases.

Keywords: bacterial vaginosis, dysbiosis, Lactobacillus iners, sexually transmitted infections, vaginal microbiota

\section{INTRODUCTION}

The vaginal microbiome plays an important role in determining human vaginal health. Using highthroughput metagenomic and $16 \mathrm{~S}$ rRNA sequencing, over 250 bacterial species have been identified in the human vagina (Fredricks et al., 2005; Chen et al., 2020). Among them, Lactobacillus is the most frequently detected microorganism in the healthy vagina, and this includes Lactobacillus crispatus, Lactobacillus iners, Lactobacillus jensenii, and Lactobacillus gasseri (Alonzo Martinez et al., 2021). For decades, Lactobacillus species have been regarded as beneficial to the vaginal econiche by preventing the invasion of pathogens through the production of organic acids, hydrogen peroxide $\left(\mathrm{H}_{2} \mathrm{O}_{2}\right)$, bacteriocin, and other antimicrobial compounds (Petrova et al., 
2015). Predisposing factors, such as menstruation, pregnancy, sexual practices, vaginal douching, and uncontrolled use of antibiotics, can rapidly alter the microbial community (Chee et al., 2020). A disruption of the vaginal ecosystem is characterized by the depletion of Lactobacillus species and the overgrowth of non-Lactobacillus microbes. Typically, the overgrowth of anaerobic bacteria can result in aberrant conditions, such as bacterial vaginosis (BV) and sexually transmitted infections (STIs), as well as pregnancy-related complications (Fredricks et al., 2005; Bautista et al., 2016; Chang et al., 2020).

Since the advent of metagenome sequencing techniques, $L$. iners has been recognized as the most prevalent Lactobacillus species in the vaginal econiche (Spear et al., 2011; Campisciano et al., 2020). This species has been initially overlooked in past bacteriologically-based studies because of its fastidious requirements and inability to grow on de Man-Rogosa-Sharpe agar (MRS), a selective culture medium that isolates vaginal Lactobacilli (Falsen et al., 1999). Furthermore, L. iners has very unique characteristics compared with other symbiotic Lactobacillus species in the vaginal econiche (Vaneechoutte, 2017). Most vaginal Lactobacillus species exert a protective effect and play a role in the resistance of the vaginal tract to colonization by pathogens. However, the relationship between $L$. iners and vaginal health is somewhat complicated and ambiguous (Petrova et al., 2017). This review aims to present the overall characteristics, an overview of different arguments, and the dual roles of $L$. iners in the vaginal econiche.

\section{CHARACTERISTICS OF $L$. iners}

\section{Culture Characteristics and Gram-Staining Properties}

L. iners was first described by Falsen et al. in 1999 in vaginal and urinary tract specimens (Falsen et al., 1999). This species had escaped our attention for a long time due to its inability to grow on MRS agar under the same culture conditions as other Lactobacillus species (De Backer et al., 2007). Nevertheless, L. iners is characterized by small, smooth, circular, translucent, and non-pigmented colonies after $24 \mathrm{~h}$ of anaerobic incubation on blood agar (Falsen et al., 1999). Indeed, most L. iners isolates can grow on MRS agar upon the addition of $1-5 \%$ sheep and human blood (Vaneechoutte, 2017). In addition, Yoshimura et al. demonstrated that $L$. iners can grow on MRS agar under anaerobic conditions for a period of at least 7 days, which is evidently longer than that of other Lactobacillus species. In MRS broth with $0.5 \%$ cysteine as the reducing agent, which created the anaerobic conditions, $L$. iners grows slowly to its highest concentration of only $10^{7} \mathrm{CFU} / \mathrm{ml}$ and then growth decreases after $12 \mathrm{~h}$ (Yoshimura et al., 2020).

L. iners was initially believed to be a Gram-positive, rodshaped, non-spore-forming, and facultative anaerobic bacterium (Falsen et al., 1999). However, several studies have reported that, unlike other Lactobacillus species, L. iners does not always clearly stain as Gram-positive, and it seems to have a coccobacillary rather than a bacillary morphology (De Backer et al., 2007;
Lebeer et al., 2008). Yoshimura et al. reported that $L$. iners was mostly Gram-negative with a very short rod shape and weak acid resistance, as it was non-viable in $\mathrm{pH} 3$ medium (Yoshimura et al., 2020). This may be the reason why L. iners was initially overlooked by culture and microscopy methods. By transmission electron microscopy, Kim et al. revealed that the peptidoglycan (PG) layer in the cell wall of $L$. iners was thin enough to give an apparent Gram-negative morphology (Kim et al., 2020). This morphological characteristic and Gram-staining property of $L$. iners are clinically very important to consider, as Nugent scoring, which is based on the Gram-staining of vaginal smears, remains a common diagnostic tool in the assessment of vaginal health (Wang et al., 2021). The Gram-negative property of $L$. iners masks the fact that it is a Lactobacillus species and this may lead to the misdiagnosis of BV, which is a condition characterized by the depletion of Lactobacillus species in Gram-stained vaginal smears under microscopy (Vaneechoutte, 2017). This may help explain why as many as $50 \%$ of women diagnosed with BV by the Nugent score are asymptomatic (Klebanoff et al., 2004).

\section{Genome Size and Function}

L. iners has the smallest genome of $\sim 1.3 \mathrm{Mbp}$ on a single chromosome among the Lactobacillus species identified so far, with its pangenome count of 2300 genes and average GC content of $\sim 33.3 \%$ (France et al., 2016). This low genome size is comparable to those of human symbionts and parasites, and is strongly indicative of a more parasitic, host-dependent lifestyle (Petrova et al., 2017). The genome of L iners seems to have undergone rapid evolution events that resulted in large-scale gene loss and genome reduction, as well as the acquisition of genes, such as iron-sulfur genes, for specific adaption to the vaginal econiche (Macklaim et al., 2011).

Comparative genome analysis revealed that $L$. iners had a severely reduced number of genes related to carbohydrate and amino acid metabolism, whereas it maintained conserved genes for largely core metabolic proteins and membrane transport genes for essential compounds from the host or the community (Macklaim et al., 2011; Kim et al., 2020). Three potential core genes (inerolysin, $\mathrm{ZnuA}$, and hsdR) were identified to be closely related to the specific adaption of $L$. iners to the vaginal environment (Kwak et al., 2020). Among them, inerolysin is an unusual pore-forming cholesterol-dependent cytolysin that is active in the acidic vaginal environment and creates aqueous pores within the cell membrane. It may be one of the essential $L$. iners genes required to stably obtain nutrients from the host (Rampersaud et al., 2011; France et al., 2016). High-affinity zinc uptake requires the binding protein ZnuA type I (ZnuA), which is essential for metal ion homeostasis in $L$. iners. ZnuA may be a key mediator of strong adhesion of $L$. iners to vaginal epithelial cells (Gabbianelli et al., 2011; McMillan et al., 2013). Type I restriction enzyme R protein (hsdR) was suggested to be involved in the defense mechanism against bacteriophage infection during BV (Miller-Ensminger et al., 2018). In addition, L. iners contains genes that encode all enzymes directly involved in PG synthesis and hydrolysis (Kim et al., 2020). The unique and thin PG layer of $L$. iners cell membranes may absorb nutrients or secrete proteins more easily than other 
Lactobacillus species, which can provide essential nutrients or respond to rapid changes in the vaginal environment (Kim et al., 2020).

\section{Ability to Produce Lactic Acid and $\mathrm{H}_{2} \mathrm{O}_{2}$}

Lactobacillus species are the main lactic acid-producing bacteria in the vagina, and they reduce the vaginal $\mathrm{pH}$ and restrict the growth of potentially harmful bacteria (Jang et al., 2019). Nevertheless, this lactic acid-producing ability is different from the main Lactobacillus species found in the vaginal microbiome (Godovalov et al., 2019). L. crispatus, L. gasseri, and L. jensenii can produce D- and L-lactic acid by fermenting glycogen, whereas $L$. iners can produce only L-lactic acid because it lacks the gene that codes for D-lactate dehydrogenase in its genome (France et al., 2016). Because of the almost complete absence of D-lactic acid, the L/D lactic acid ratio is highest in $L$. iners. Witkin et al. reported that the isomers of lactic acid have different effects on the host immune system (Witkin et al., 2013). The L/D lactic acid ratio in the vagina may elevate extracellular matrix metalloproteinase inducer (EMMPRIN) and subsequently activate matrix metalloproteinase- 8 (MMP-8), which facilitates the breakdown of the extracellular matrix, helps bacteria transverse the cervix, and initiates upper genital tract infections (Beghini et al., 2015). Additionally, D-lactic acid has been reported to have a greater inhibitory effect on exogenous bacteria than L-lactic acid (Tachedjian et al., 2017). Therefore, it seems that L-lactic acid renders $L$. iners less effective in preventing the invasion of pathogens (Basavaprabhu et al., 2020).

Srinivasan et al. reported that microbiomes abundant in L. crispatus were consistently strongly associated with low vaginal $\mathrm{pH}$, but this was not the case for women with $L$. iners overgrowth (Srinivasan et al., 2012). In fact, L. iners was very weak in a vaginal environment with low $\mathrm{pH}$, failing to maintain intravaginal acidity. A high vaginal $\mathrm{pH}$ is a characteristic of $\mathrm{BV}$, a condition in which Gardnerella vaginalis and $L$. iners are generally found in the vaginal econiche but other Lactobacillus species are rarely found (Muzny et al., 2018; Pleckaityte, 2019). In addition, $L$. iners does not have the molecular and cellular machinery to produce $\mathrm{H}_{2} \mathrm{O}_{2}$ through pyruvate oxidation. The production of $\mathrm{H}_{2} \mathrm{O}_{2}$ is considered to be one of the mechanisms by which Lactobacillus species can prevent anaerobic bacteria from colonizing the vagina (Felten et al., 1999; Ojala et al., 2014). As such, when pathogenic bacteria challenge the vaginal environment, $L$. iners cannot resist the overgrowth of pathogenic bacteria and the increase of $\mathrm{pH}$, whereas it may persist in dysbiosis (Chee et al., 2020).

\section{Adhesive Capability of $L$. iners}

The adherence of vaginal Lactobacillus species to host cells is believed to play a role in the exclusion of pathogenic microorganisms through a mechanism that involves the blocking of their binding sites on vaginal epithelial cells (Pino et al., 2019; Mane et al., 2020). Although L. iners lacks most of the main adhesion molecules of Lactobacillus species (Morris et al., 2012), it still shows a strong adhesive ability to vaginal epithelial cells (McMillan et al., 2013). Fibronectin is an insoluble glycoprotein in the extracellular matrix of the vaginal epithelium (Park et al., 2012). The L. iners genome encodes a fibronectin-binding protein that contains a motif (fibronectinbinding protein A) common to pathogenic strains of Staphylococcus aureus, thereby mediating the adhesion and the invasion of S. aureus to host cells (Macklaim et al., 2011; Macklaim et al., 2013). McMillan et al. demonstrated that $L$. iners bound significantly stronger to human fibronectin than other Lactobacillus species at a more neutral $\mathrm{pH}$, which may contribute to the persistence of $L$. iners in the vagina despite the presence of pathogens or treatment with antibiotics (McMillan et al., 2013). An in vitro study reported that L. iners may increase the adhesion of BV-causing G. vaginalis (Castro et al., 2013). It was also demonstrated that $L$. iners produces inerolysin, a poreforming protein typically found in pathogenic bacteria, which can enhance the adhesive ability (Rampersaud et al., 2011; Ragaliauskas et al., 2019). These findings indicate that the unique adhesive function of $L$. iners reduces the protection of the healthy vaginal microbiome from pathogenic bacteria.

\section{Requirement of Nutrients From Exogenous Sources}

L. iners has an unusually small genome with reduced metabolic capabilities, but it contains a broader array of genes that was probably acquired from foreign sources. The nutrient requirements of this species are more complex than those of other vaginal Lactobacillus species, thereby allowing $L$. iners to adapt to the diverse niche in the vagina (Macklaim et al., 2011). The fluctuation of hormones and other factors may affect the vaginal environment, resulting in changes in mucus and glycogen production, $\mathrm{pH}$, and microbial species, which may provide essential nutrients for L. iners (Kwak et al., 2020). Genome analysis has indicated a higher dependence of $L$. iners on exogenous sources of amino acids (France et al., 2016). Furthermore, L. iners has the molecular and cellular machinery to ferment glucose, maltose, trehalose, and mannose, among which glucose and maltose are common glycogenolysis products (France et al., 2016). Macklaim et al. reported that L. iners genes for the uptake of mannose and maltose, genes for glycogen decomposition, as well as genes for mucin and glycerol transport, were strongly upregulated in BV (Macklaim et al., 2013). Although no iron uptake system has been identified in L. iners, ferrochelatase, which is capable of catalyzing ferrous ion and binding protoporphyrin IX to form heme, was detected in L. iners (Macklaim et al., 2011).

The ability of $L$. iners to produce inerolysin may be one of the most important factors influencing its ability to acquire nutrients from the vaginal environment. L. iners is the only Lactobacillus species known to code for inerolysin, which is related to intermedilysin $(69.2 \%$ similarity) and vaginolysin $(68.4 \%$ similarity) produced by Streptococcus intermedius and G. vaginalis, respectively (Rampersaud et al., 2011). Over 10\% of genes coding for inerolysin in L. iners are more highly expressed in dysbiosis than in balanced microbial environments (Macklaim et al., 2013). This cytolysin can liberate resources directly from host tissues or cells, which necessitates that $L$. iners acquire its nutrients from the host in a symbiotic way (Macklaim et al., 
2011). In other words, this characteristic may give $L$. iners a competitive advantage in the vaginal environment when nutrients are scarce, especially under potentially adverse conditions, such as BV, when other Lactobacillus species cannot colonize the vagina (Zozaya-Hinchliffe et al., 2010; Li and Ma, 2020).

\section{L. iners AND WOMEN DISEASES}

\section{L. iners and Vaginal Dysbiosis}

Compared with intestinal microflora, a typical feature of the vaginal microbial environment in healthy individuals is its extremely low bacterial diversity (Ravel et al., 2011; Collins et al., 2018). There are five major community-state types (CSTs) in healthy premenopausal women, namely, L. crispatus-dominated CST I, L. gasseridominated CST II, L. iners-dominated CST III, and L. jenseniidominated CST V, whereas CST IV is characterized by the absence of Lactobacillus species (Wells et al., 2020). Vaginal dysbiosis, which is defined by a high bacterial diversity and a mixture of anaerobic bacteria, is frequently associated with a variety of gynaecological diseases (Eastment and McClelland, 2018; Chee et al., 2020; Chen et al., 2021).

L. iners can be predominant in the vagina of healthy women, or in those with vaginal dysbiosis, such as BV, or even in those receiving antimicrobial therapy (Ferris et al., 2007; Goodfellow et al., 2021). Many studies have reported that the presence of $L$. crispatus in the vagina is associated with good health, whereas communities dominated by $L$. iners fail to provide sufficient protection against vaginal dysbiosis (Petricevic et al., 2014; France et al., 2016; Tortelli et al., 2020). The existence of $L$. iners is related to higher levels of proinflammatory factors, such as interleukin-1 $\alpha$, interleukin-18, macrophage migration inhibitory factor, and tumor necrosis factor- $\alpha$, which are responsible for the activation of an inflammatory response in the vagina (De Seta et al., 2019). L. iners is even believed to play a role in the onset of vaginal dysbiosis (Petrova et al., 2017), although the precise role of $L$. iners remains debated. However, it seems that the abundance of $L$. iners remains relatively constant, and $L$. iners is not easily displaced by pathogens or infectious conditions. In cases of BV, L. iners, rather than $L$. crispatus, usually coexists with other potentially harmful bacteria that colonize the vagina (Ferris et al., 2007; Zozaya-Hinchliffe et al., 2010). The ability of $L$. iners to adapt to dysbiosis, despite its small genome, may be related to its changes in genes involved in metabolism and cytolysis, as well as antibacteriophage defense genes, to changing conditions in the vagina (Borgdorff et al., 2016; Leizer et al., 2018). The remarkable ability of $L$. iners to survive under various conditions indicates that this species may be an important member of the host's defense and may be a persistent symbiotic Lactobacillus species that can maintain and restore the vaginal microbiome (Macklaim et al., 2011).

\section{L. iners and BV}

$\mathrm{BV}$ is the most common type of vaginitis in women of childbearing age. It is characterized by a significant reduction or disappearance of Lactobacillus species, accompanied by the emergence of more diverse microbiota dominated by anaerobic and facultative bacteria such as Gardnerella species, Prevotella species, and A. vaginae (Fredricks et al., 2005; Lee et al., 2020; Witkin et al., 2021). However, L. iners is usually the only vaginal Lactobacillus species coexisting with BV-associated bacteria that can be detected during BV (Macklaim et al., 2011; Santiago et al., 2012). It can persist under the drastically changing vaginal environment of BV due to its ability to respond and regulate its genomic functions (Macklaim et al., 2013). The increased gene expression of $L$. iners may lead to the production of succinate and other short-chain fatty acids and the increase in the $\mathrm{pH}$ value in the BV environment (Macklaim et al., 2013). To adapt to the $\mathrm{BV}$ environment, $L$. iners can increase the expression of inerolysin and mucin, and promote the production of glycerol and the expression of related metabolic enzymes, which ensures its acquirement of nutrients from foreign sources (Macklaim et al., 2013). In addition, bacteriophages were one of the reasons for the sudden decrease of Lactobacillus species during BV, whereas L. iners can upregulate defense systems such as the type I RM system and CRISPR, as well as its specific hsdR gene, to resist bacteriophage invasion during BV (Kwak et al., 2020). Nevertheless, a recent study discovered three active peptides of bacteriocin produced by a human intestinal strain named Lactobacillus paragasseri. These bacteriocins have strong selective inhibitory activity against $L$. iners, whereas L. crispatus, L. jensenii, and L. gasseri were only slightly inhibited, indicating that these Lactobacillus-derived effective inhibitors of $L$. iners can be combined with metronidazole to improve the current BV treatments (Nilsen et al., 2020).

As the coexistence of $L$. iners in BV is different from that of other Lactobacillus species, the prevalence of $L$. iners can be used as a microbial indicator to predict the onset of $\mathrm{BV}$ or the intermediate BV status (Basavaprabhu et al., 2020). Furthermore, L. iners is metronidazole-resistant, and it was found to be the predominant Lactobacillus species, even after treatment of BV with metronidazole (Ferris et al., 2007; Srinivasan et al., 2010; Mayer et al., 2015; Lehtoranta et al., 2020). Compared with other more protective Lactobacillus species, which hardly exist during $\mathrm{BV}, L$. iners showed a stronger competitive advantage and coexisted in the disrupted microbiome (Nilsen et al., 2020). It has been proposed that $L$. iners facilitates the transition between BV and non-BV states (Shipitsyna et al., 2013; Petrova et al., 2015). Interestingly, it has been reported that even after $\mathrm{BV}$ treatment, the vaginal microbiome does not change from the $L$. iners-dominant state to the L. crispatus-dominated state (Lambert et al., 2013). Therefore, the persistence of $L$. iners may lead to long-term vaginal dysbiosis, especially after repeated treatment cycles of BV (Nilsen et al., 2020). Further studies are needed to clarify whether this species is only a biomarker of the vaginal microbiota transition or a contributing factor of BV.

\section{L. iners and Biofilm Formation}

Biofilms are bacterial structures tightly attached to a surface, and they are known to be more resistant to the host immune response and antibiotic therapy than planktonic cells (Hall-Stoodley et al., 
2012). It has been shown that biofilm formation on vaginal epithelial cells is strongly associated with vaginal infections (Costerton et al., 1999; Srinivasan and Fredricks, 2008). There is sufficient evidence that $\mathrm{BV}$ associates with the presence of a dense polymicrobial biofilm, in which $G$. vaginalis is the dominant bacterial strain on the vaginal epithelium (Machado et al., 2015; Rosca et al., 2020). It has been hypothesized that Gardnerella spp. initiate biofilm formation, which supports the attachment of other BV-associated bacteria (BVAB) to the vaginal epithelium, further enhancing the biofilm thickness (Muzny et al., 2019). Moreover, Gardnerella biofilms serve as barriers to antibiotics and function to protect other BVAB by preventing the penetration of antibiotics (Gustin et al., 2021). It is generally believed that the high rate of $\mathrm{BV}$ recurrence is due to the formation of biofilms that protect the bacteria from antibiotic treatment, and even serve as a reservoir for pathogen regrowth (Bradshaw et al., 2006; Gottschick et al., 2017).

Vaginal indigenous Lactobacilli are believed to prevent the colonization of pathogenic bacteria through steric hindrance or receptor masking in the mucosa (Zarate and Nader-Macias, 2006). Previous studies have used a Lactobacillus probiotic approach in an attempt to clear the polymicrobial biofilms, essentially impeding bacterial virulence and suppressing infection in the human vagina (Saunders et al., 2007; Hardy et al., 2017; Chee et al., 2020). Lactobacillus plantarum was reported to significantly reduce the adhesion of Escherichia coli, Salmonella typhimurium, Staphylococcus aureus, and Pseudomonas aeruginosa in the HT-29 cell line, which made it a potential anti-biofilm agent for BV treatment (Liu et al., 2017). Saunders et al. reported that G. vaginalis biofilms grown in vitro were displaced with Lactobacillus reuteri RC-14, and to a limited extent with L. iners (Saunders et al., 2007). Castro et al. demonstrated that $L$. crispatus drastically reduced the adhesion of $G$. vaginalis strains, both from a healthy woman and a woman with $\mathrm{BV}$, to cervical epithelial cells. Interestingly, $L$. iners significantly reduced the adhesion of $G$. vaginalis strains from a healthy woman, but markedly enhanced pathogenic $G$. vaginalis adhesion (Castro et al., 2013), suggesting that L. iners can cohabitate with BV-associated $G$. vaginalis and may contribute to $G$. vaginalis-dominated biofilm formation (Gottschick et al., 2017). In addition, it is well known that Candida species, mainly C. albicans, can form thick and tough biofilms, which greatly increases the tolerance to antifungal drugs during the treatment of recurrent vulvovaginal candidiasis (Taff et al., 2013). Mckloud et al. reported the ability of various Lactobacillus species to inhibit C. albicans biofilm formation and biofilm-related gene expression when cocultured (McKloud et al., 2021). Lactobacillus rhamnosus could down-regulate $C$. albicans biofilm-related gene expression. Conversely, coculture with $L$. iners resulted in an up-regulation of biofilm-related gene expression (ALS3 and ECE1), suggesting that the presence of $L$. iners may be indicative of a shift to vaginal dysbiosis; therefore, it should not be used as a probiotic intervention for C. albicans infection (Ponomarova et al., 2017). A further understanding of the interactions between vaginal commensal Lactobacilli and the structure and function of biofilms is of extreme importance to identify novel treatment approaches for biofilm-associated infections (Falconi-McCahill, 2019).

\section{L. iners and STIs}

Previous studies have reported that L. crispatus-dominated vaginal microbiomes associate with a lower prevalence of STIs, whereas BV associates with an elevated risk of STIs such as infection with Chlamydia trachomatis, human immunodeficiency virus (HIV), Neisseria gonorrhoeae, cytomegalovirus, and herpes simplex virus-2 (Bayigga et al., 2019; Gondwe et al., 2020; Redelinghuys et al., 2020). Van Houdt et al. reported that the vaginal microbiome dominated by $L$. iners at baseline significantly increased the risk of acquiring C. trachomatis infection one year later (van Houdt et al., 2018). A lack of D-lactic acid in the $L$. iners-dominated vaginal microbiome may increase the ability of HIV to transverse the cervicovaginal mucus by modulating cervical integrity (Witkin, 2015; Reimers et al., 2016; Hoang et al., 2020). Interestingly, Mehta et al. and Reimers et al. demonstrated that the vaginal microbiome did not differ between HIV-positive and HIVnegative black women in the United States (Mehta et al., 2015; Reimers et al., 2016). However, Spear et al. conversely observed that the percentage of $L$. iners was significantly higher in HIVnegative African Americans than in HIV-positive African Americans (Spear et al., 2011). The reason for these inconsistent results may be differences in the genetic background or complicated social and behavioral factors in black women, as black women without BV were more likely to have vaginal microbiomes dominated by L. iners (Fettweis et al., 2014; Wells et al., 2020). The precise role of L. iners in HIV infection should be further examined. Many studies reported a higher diversity of vaginal microbes and a lower abundance of Lactobacillus species among HPV-positive women (Lee et al., 2013; Oh et al., 2015; Reimers et al., 2016). Norenhag et al. showed that the vaginal microbiome dominated by $L$. iners was associated with high-risk HPV infection compared with $L$. crispatus (Norenhag et al., 2020). It can be speculated that vaginal dysbiosis may affect the host's innate immunity against HPV infection, resulting in dysplasia/cervical cancer (Kyrgiou et al., 2017). These findings indicate that $L$. iners may exhibit rapid changes in the composition of the vaginal microbiome similar to BV and could be a valuable biomarker of the dynamic vaginal environment under STIs (Ravel et al., 2013; van Houdt et al., 2018).

\section{L. iners and Preterm Birth (PTB)}

It is especially important to maintain the natural and healthy balance of Lactobacillus species in the vaginal microbiome during pregnancy (Zheng et al., 2019; Juliana et al., 2021). Earlier studies confirmed that high estradiol levels and the consequent high glycogen levels in the vagina during pregnancy result in stronger vaginal acidification, thereby promoting the prevalence of Lactobacillus species as gestation progresses (Aagaard et al., 2012; Basavaprabhu et al., 2020). However, many studies have indicated that the L. iners- 
dominated vaginal microbiome was more likely to shift towards dysbiosis during pregnancy (Mls et al., 2019; Kumar et al., 2021; Sarmento et al., 2021). In our previous study, we found that the abundance of $L$. iners decreased significantly in the second and third trimester, whereas that of L. crispatus increased in the second trimester compared with the first trimester in healthy pregnant women (Zheng et al., 2019). In addition, we observed that the increase in the abundance of $L$. iners, but not that of $L$. crispatus, was related to the increase in vaginal cleanliness and positive leukocyte esterase activity, which is consistent with the results of a previous study (Vaneechoutte, 2017).

Increasing evidence indicates that $\mathrm{BV}$ is one of the major etiological causes for adverse pregnancy outcomes, especially PTB (Guerra et al., 2006; Basavaprabhu et al., 2020; Redelinghuys et al., 2020). The L. iners-dominated vaginal microbiome, a so-called 'intermediate microflora' and a typical feature of $\mathrm{BV}$, is speculated to be a risk factor for PTB (Petricevic et al., 2014; Kindinger et al., 2017). Petricevic et al. suggested that the prevalence of $L$. iners detected in vaginal smears of healthy women in early pregnancy can associate with PTB (Petricevic et al., 2014). This was also demonstrated by Kindinger et al., who reported that the vaginal microbiome dominated by $L$. iners at 16 weeks of gestation is a risk factor for both a short cervix and early PTB ( $<34$ weeks), whereas $L$. crispatus dominance is protective against PTB in a more ethnically diverse cohort (Kindinger et al., 2017). Recent studies from different countries also showed a significant association between $L$. iners and an increased prevalence of PTB (Elovitz et al., 2019; Aslam et al., 2020; Goodfellow et al., 2021; Kumar et al., 2021; Payne et al., 2021; Sarmento et al., 2021). However, several studies reported no significant association between $L$. iners and PTB (Callahan et al., 2017; Blostein et al., 2020; Witkin et al., 2021). L. iners was also demonstrated to be the most abundant Lactobacillus species among pregnant black women (Wells et al., 2020). However, most studies did not identify a significant relationship between the Lactobacillusdominant vaginal microbiome and PTB in pregnant black women (Hyman et al., 2014; Nelson et al., 2016; Subramaniam et al., 2016; Stout et al., 2017). Conversely, three studies reported that $L$. iners was associated with a decreased risk of PTB (Fettweis et al., 2019; Tabatabaei et al., 2019; Park et al., 2021). Therefore, the association between $L$. iners and PTB risk is controversial (Table 1). Presently, it is believed that the vaginal microbiome in black women does not play an important role in the pathogenesis of PTB, as it does in Caucasians and Asians (Kindinger et al., 2017). Furthermore, the limited sample size, the time of sample collection, differences in the definition of PTB, ethnical and geographical variations, and differences in the methodology of strain identification, as well as complicated clinical conditions such as genetic abnormalities or a history of PTB, were confounding factors that impacted the results (Ravel et al., 2011; Jespers et al., 2012; Mehta et al., 2020; Wells et al., 2020).

According to the features of $L$. iners and its lack of protection against pathogens when it is the only Lactobacillus species in the vagina, some researchers have suggested that $L$. iners cannot be responsible for infections during pregnancy (Petricevic et al., 2014; Peelen et al., 2019). Indeed, because the vaginal microbiome dominated by $L$. iners is relatively unstable, there is a tendency for transition to BV-associated CST-IV during pregnancy (Verstraelen et al., 2009). In addition, the L. inersdominated vaginal microbiome may increase the risk of PTB by modulating local tissue inflammation and cervical integrity, thereby disrupting chemical and mechanical mucosal protective barriers against ascending infections (Kindinger et al., 2017). Further studies are needed to clarify the potential mechanisms between the $L$. iners-dominated vaginal microbiome and PTB.

\section{L. iners and Infertility}

Previous studies have reported that up to $40 \%$ of patients who failed assisted reproduction by in vitro fertilization (IVF) had an abnormal reproductive tract microbiome (Fanchin et al., 1998; Moore et al., 2000; Koedooder et al., 2019). Vaginal dysbiosis, including an elevated $\mathrm{pH}$ value, increased flora diversity, BV, vulvovaginal candidiasis, and trichomonal vaginitis, are recognized as risk factors for infertility (Campisciano et al., 2017; Moumne et al., 2021). Campisciano et al. reported that the abundance of $L$. iners was associated with an increased infertility rate (Campisciano et al., 2020). Chen et al. also recently reported that the L. iners-dominated vaginal microbiome was associated with tubal infertility and $C$. trachomatis infection (Chen et al., 2021). As a transitional species, L. iners may facilitate the transition between an abnormal and a normal vaginal microbiome under treatment or artificially high estrogen levels that are needed for IVF (Kindinger et al., 2017; Kosti et al., 2020). It is believed that the L. iners-dominated vaginal microbiome is an unfavorable factor for pregnancy.mk

\section{L. iners AND THE MENSTRUATION CYCLE}

The Human Microbiome Project shows that in the microbial community for all body parts, including the vagina, withinsubject variations over time are consistently lower than betweensubject variations (Human Microbiome Project, 2012). The menstrual cycle is one of the most important factors disturbing the diversity of the vaginal microbiome (Chaban et al., 2014; Chen et al., 2021). L. crispatus usually dominates the vagina of reproductive-age women, whereas $L$. iners overgrows and replaces $L$. crispatus during the menstruation cycle (Gajer et al., 2012; Santiago et al., 2012). A recent study reported that L. iners was the most recurrent microbe in the follicular phase; L. iners and CST IV (microbial diversity) were predominant in the periovulatory phase; and in the luteal phase, the most frequent type was CST IV (Alonzo Martinez et al., 2021). Indeed, the abundance of $L$. iners remarkably increases during menses, frequently in conjunction with an increase of $G$. vaginalis and/or Atopobium vaginae; however, they subsequently decrease after menses without intervention (Jespers et al., 2012; Petrova et al., 2015). As dynamic changes in the vaginal econiche were characterized at different time points in the menstruation cycle within the same individual, the moment of sampling relative to the menstrual cycle is very important for vaginal community analysis. 


\begin{tabular}{|c|c|c|c|c|c|c|}
\hline $\begin{array}{l}\text { Author } \\
\text { (year) }\end{array}$ & Country & $\begin{array}{l}\text { Time of sample } \\
\text { collection }\end{array}$ & Sample size & $\begin{array}{l}\text { Tools implied } \\
\text { for identification }\end{array}$ & Main findings & References \\
\hline $\begin{array}{l}\text { Petricevic } \\
\text { et al. }\end{array}$ & Austria & $\begin{array}{l}\text { At } 11-14 \text { weeks of } \\
\text { gestation }\end{array}$ & $\begin{array}{l}111 \text { women (white European, } \\
\text { Middle Eastern, Asian) }\end{array}$ & $\begin{array}{l}\text { PCR-DGGE and } \\
\text { sequencing }\end{array}$ & $\begin{array}{l}\text { L. iners was the predominant vaginal Lactobacillus spp. in women who delivered preterm } \\
\text { newborns. L. iners was predominantly present in } 11 / 13(85 \%) \text { of women who delivered preterm } \\
\text { newborns and in only } 16 / 98(16 \%) \text { of women who delivered at term }(p<0.001) \text {. }\end{array}$ & $\begin{array}{l}\text { (Petricevic } \\
\text { et al., 2014) }\end{array}$ \\
\hline $\begin{array}{l}\text { Kindinger } \\
\text { et al. }\end{array}$ & $\begin{array}{l}\text { United } \\
\text { Kingdom }\end{array}$ & $\begin{array}{l}\text { At } 16 \text { weeks of } \\
\text { gestation }\end{array}$ & $\begin{array}{l}161 \text { women (30 Black, } 104 \\
\text { Caucasian, } 27 \text { Asian) }\end{array}$ & $\begin{array}{l}\text { 16S rRNA gene } \\
\text { sequencing at } \\
\text { V1-V3 region }\end{array}$ & $\begin{array}{l}\text { L. iners dominance of the vaginal microbial community at } 16 \text { weeks of gestation was significantly } \\
\text { associated with both a short cervix }<25 \mathrm{~mm} \text { and early PTB ( }<34 \text { weeks). By contrast, L. crispatus } \\
\text { dominance was highly predictive of TB. }\end{array}$ & $\begin{array}{l}\text { (Kindinger } \\
\text { et al., 2017) }\end{array}$ \\
\hline $\begin{array}{l}\text { Callahan } \\
\text { et al. }\end{array}$ & $\begin{array}{l}\text { United } \\
\text { States }\end{array}$ & Weekly & $\begin{array}{l}\text { Low-risk cohort: } 39 \text { women; } \\
\text { High-risk cohort: } 96 \text { women }\end{array}$ & $\begin{array}{l}16 S \text { rRNA gene } \\
\text { sequencing at } \\
\text { V4 region }\end{array}$ & $\begin{array}{l}\text { L. crispatus was associated with the low risk of PTB in low- and high-risk cohorts, whereas no } \\
\text { significant association was detected for } L \text {. iners. A subspecies clade of Gardnerella vaginalis } \\
\text { explained the genus association with PTB. }\end{array}$ & $\begin{array}{l}\text { (Callahan } \\
\text { et al., 2017) }\end{array}$ \\
\hline $\begin{array}{l}\text { Tabatabaei } \\
\text { et al. }\end{array}$ & Canada & $\begin{array}{l}\text { At } 8-13 \text { weeks of } \\
\text { gestation }\end{array}$ & $\begin{array}{l}94 \text { spontaneous PTB cases, } \\
356 \text { term controls }\end{array}$ & $\begin{array}{l}16 \mathrm{~S} \text { rRNA gene } \\
\text { sequencing at } \\
\text { V4 region }\end{array}$ & $\begin{array}{l}\text { Lactobacillus gasseri/L. johnsonii, L. crispatus (99\%)/L. acidophilus (99\%), L. iners (99\%)/Ralstonia } \\
\text { solanacearum (99\%) and Bifidobacterium longum/Bifidobacterium breve were associated with a } \\
\text { decreased risk of early but not late spontaneous PTB. }\end{array}$ & $\begin{array}{l}\text { (Tabatabaei } \\
\text { et al., 2019) }\end{array}$ \\
\hline Elovitz et al. & $\begin{array}{l}\text { United } \\
\text { States }\end{array}$ & $\begin{array}{l}\text { At } 16-20 \text { weeks, } 20- \\
24 \text { weeks and } 24-28 \\
\text { weeks of gestation }\end{array}$ & $\begin{array}{l}539 \text { women ( } 402 \text { African } \\
\text { American, } 115 \text { white, } 22 \text { other) }\end{array}$ & $\begin{array}{l}\text { 16S rRNA gene } \\
\text { sequencing at } \\
\text { V3-V4 region }\end{array}$ & $\begin{array}{l}\text { In non-African American women, L. iners and A. vaginae were significantly associated with } \\
\text { increased rates of spontaneous PTB. }\end{array}$ & $\begin{array}{l}\text { (Elovitz et al., } \\
\text { 2019) }\end{array}$ \\
\hline $\begin{array}{l}\text { Fettweis } \\
\text { et al. }\end{array}$ & $\begin{array}{l}\text { United } \\
\text { States }\end{array}$ & $\begin{array}{l}\text { At prenatal visit, at } \\
\text { triage }\end{array}$ & $\begin{array}{l}45 \text { spontaneous PTB cases } \\
\text { and } 90 \text { term controls (African } \\
\text { American predominantly) }\end{array}$ & $\begin{array}{l}\text { 16S rRNA gene } \\
\text { sequencing at } \\
\text { V1-V3 region }\end{array}$ & $\begin{array}{l}\text { L. crispatus increased in abundance during pregnancy in women who delivered preterm } \\
\text { newborns. Women who delivered at term exhibited significant decreases in the abundance of } A \text {. } \\
\text { vaginae and } G \text {. vaginalis, and an increase in the abundance of } L \text {. iners. }\end{array}$ & $\begin{array}{l}\text { (Fettweis } \\
\text { et al., 2019) }\end{array}$ \\
\hline Aslam et al. & Pakistan & Not available & $\begin{array}{l}8 \text { term vaginal swabs, } 8 \\
\text { preterm vaginal swabs, and } 8 \\
\text { preterm placenta tissues }\end{array}$ & $\begin{array}{l}\text { 16S rRNA gene } \\
\text { sequencing at } \\
\text { V1-V2 region }\end{array}$ & $\begin{array}{l}\text { Metagenomics data of vaginal swabs and placental tissues from severe PTB indicated that } L \text {. iners } \\
\text { was the main difference between term and preterm deliveries. Overall, the lack of Lactobacillus } \\
\text { species or the presence of rogue Lactobacillus species, such as } L \text {. iners and } L \text {. vaginilis, was } \\
\text { associated with PTB. }\end{array}$ & $\begin{array}{l}\text { (Aslam } \\
\text { et al., 2020) }\end{array}$ \\
\hline $\begin{array}{l}\text { Blostein } \\
\text { et al. }\end{array}$ & Peru & $\begin{array}{l}\text { Before } 16 \text { weeks of } \\
\text { gestation ( } 9 \text { weeks on } \\
\text { average) }\end{array}$ & $\begin{array}{l}25 \text { PTB cases and } 100 \text { term } \\
\text { controls }\end{array}$ & $\begin{array}{l}16 S \text { rRNA gene } \\
\text { sequencing at } \\
\text { V4 region }\end{array}$ & $\begin{array}{l}\text { Overall, no CST (diverse, Lactobacillus-dominated, or L. iners-dominated) was associated with PTB } \\
\text { in crude or adjusted logistic models, whereas women with Lactobacillus-dominated CSTs were less } \\
\text { likely to have PTB than those with diverse CST among women sampled before } 12 \text { weeks of } \\
\text { gestation. }\end{array}$ & $\begin{array}{l}\text { (Blostein } \\
\text { et al., 2020) }\end{array}$ \\
\hline $\begin{array}{l}\text { Sarmento } \\
\text { et al. }\end{array}$ & Brazil & In the second trimester & 146 women & $\begin{array}{l}\text { 16S rRNA gene } \\
\text { sequencing at } \\
\text { V1-V3 region }\end{array}$ & $\begin{array}{l}\text { L. iners was the dominant vaginal bacterium in } 61.5 \% \text { of women with spontaneous PTB but only in } \\
31.2 \% \text { of those who delivered at term }(p=0.035) \text {. }\end{array}$ & $\begin{array}{l}\text { (Sarmento } \\
\text { et al., 2021) }\end{array}$ \\
\hline $\begin{array}{l}\text { Kumar } \\
\text { et al. }\end{array}$ & India & $\begin{array}{l}\text { In each trimester of } \\
\text { pregnancy }\end{array}$ & $\begin{array}{l}18 \text { PTB cases and } 20 \text { term } \\
\text { controls }\end{array}$ & $\begin{array}{l}\text { 16S rRNA gene } \\
\text { sequencing at } \\
\text { V3-V4 region }\end{array}$ & $\begin{array}{l}\text { A significantly higher abundance of } L \text {. iners (all trimesters), Megasphaera sp (first trimester), } \\
\text { Gardnerella vaginalis (second trimester), and Sneathia sanguinegens (second trimester) was identified } \\
\text { in preterm samples, whereas a higher abundance of } L \text {. gasseri (third trimester) was observed in term } \\
\text { samples. }\end{array}$ & $\begin{array}{l}\text { (Kumar } \\
\text { et al., 2021) }\end{array}$ \\
\hline Witkin et al. & Brazil & In the second trimester & 613 women & $\begin{array}{l}\text { 16S rRNA gene } \\
\text { sequencing at } \\
\text { V1-V3 region }\end{array}$ & $\begin{array}{l}\text { Spontaneous PTB occurred in } 9.6 \%, 9.3 \% \text {, and } 6.9 \% \text { of women when G. vaginalis, } L \text {. iners, or } L \text {. } \\
\text { crispatus was the dominant species, respectively, but the differences were not statistically significant. }\end{array}$ & $\begin{array}{l}\text { (Witkin } \\
\text { et al., 2021) }\end{array}$ \\
\hline $\begin{array}{l}\text { Goodfellow } \\
\text { et al. }\end{array}$ & $\begin{array}{l}\text { United } \\
\text { Kingdom }\end{array}$ & $\begin{array}{l}\text { At } 15-22 \text { weeks of } \\
\text { gestation }\end{array}$ & $\begin{array}{l}109 \text { high-risk women and } 145 \\
\text { low-risk women }\end{array}$ & $\begin{array}{l}\text { 16S rRNA gene } \\
\text { sequencing at } \\
\text { V3-V4 region }\end{array}$ & $\begin{array}{l}\text { L. iners achieved higher bacterial loads compared to the other Lactobacillus species and associated } \\
\text { with early spontaneous PTB/PPROM recurrence. }\end{array}$ & $\begin{array}{l}\text { (Goodfellow } \\
\text { et al., 2021) }\end{array}$ \\
\hline Park et al. & Korea & $\begin{array}{l}\text { At } 15-34 \text { weeks of } \\
\text { gestation }\end{array}$ & $\begin{array}{l}38 \text { PTB cases and } 56 \text { term } \\
\text { controls }\end{array}$ & $\begin{array}{l}\text { Multiplex } \\
\text { quantitative real- } \\
\text { time PCR }\end{array}$ & $\begin{array}{l}\text { Although most values for single bacteria were not statistically significant, the mean value of the total } \\
\text { Bacillus class showed a significant difference between PTB and TB groups, in which the mean value } \\
\text { of } L \text {. iners showed a significant increase in the TB group. }\end{array}$ & $\begin{array}{l}\text { (Park et al., } \\
\text { 2021) }\end{array}$ \\
\hline Payne et al. & Australia & $\begin{array}{l}\text { At } 12-23 \text { weeks of } \\
\text { gestation }\end{array}$ & $\begin{array}{l}936 \text { women (white race } \\
\text { predominantly) }\end{array}$ & $\begin{array}{l}\text { Quantitative } \\
\text { PCR }\end{array}$ & $\begin{array}{l}\text { Women who delivered at term had a higher level of } L \text {. crispatus, } L \text {. gasseri, or } L \text {. jensenii DNA in their } \\
\text { vaginal swabs. In the remaining women, a specific microbial DNA signature was identified, which was } \\
\text { strongly predictive of spontaneous PTB risk, consisting of G. vaginalis, } L \text {. iners, and Ureaplasma } \\
\text { parvum DNA. }\end{array}$ & $\begin{array}{l}\text { (Payne } \\
\text { et al., 2021) }\end{array}$ \\
\hline
\end{tabular}

PTB, preterm birth; TB, term birth; PPROM, preterm prelabor rupture of membranes; DGGE, denaturing gradient gel electrophoresis. 


\section{ANTI-MICROBIAL AND IMMUNE- INDUCING ACTIVITY OF $L$. iners}

L. iners is the most common and persistent vaginal symbiotic Lactobacillus species with good adaptability to the complex and dynamically changing vaginal environment (Borgdorff et al., 2016; Kwak et al., 2020). Under fluctuating environmental conditions, other Lactobacillus species may not survive, while L. iners persists with relatively constant abundance due to its ability to respond and regulate its genomic functions, such as specific carbohydrate uptake, fibronectin-binding protein activity, bacteriophage defense, and inerolysin synthesis (Rampersaud et al., 2011; Macklaim et al., 2013; McMillan et al., 2013; Kwak et al., 2020). This remarkable ability to survive under a range of conditions contributes to $L$. iners' being a dominant species when the microbiome is in a transitional stage (Jakobsson and Forsum, 2007), suggesting that L. iners may be an important member of the host defense mechanism as a persistent mutualistic lactobacilli, and even promote the restoration of a healthy vaginal microbiome (Ravel et al., 2011; France et al., 2016).

In fact, several studies have confirmed many probiotic characteristics of $L$. iners. It has many ecological functions, such as lactic acid production, that are similar to those of other Lactobacillus species (Linhares et al., 2011; O'Hanlon et al., 2011). Although the genome of L. iners lacks most of the adhesion factors of other Lactobacillus species, it can still adhere strongly to vaginal epithelial cells (Morris et al., 2012; McMillan et al., 2013).Thus, L. iners shows the similar phenotypic traits of colonization and host interaction, as well as excluding pathogens, as other vaginal Lactobacillus species (Osset et al., 2001). Shipitsyna et al. reported the loss of $L$. iners during BV and suggested that it was not the key pathogen causing the disease (Shipitsyna et al., 2013). L. iners can destroy or replace G. vaginalis to form biofilms in vitro (Hummelen et al., 2010; Zhou et al., 2010). Macklaim et al. demonstrated that some specific functions of L. iners, such as the expression of cytokines, absorption of exogenous sources, and bacteriophage defense, facilitated the harsh conditions in the vagina, including BV (Macklaim et al., 2013). L. iners prevents harmful bacteria from obtaining important nutrients, such as iron, and inhibits their sustained growth by triggering the innate immune system in vaginal epithelial cells (Vaneechoutte, 2017). In addition, the anti-inflammatory effects of $L$. iners were observed through specific molecular interactions between vaginal epithelial cells (Rose et al., 2012).

The $L$. iners-dominated vaginal microbiome was associated with the induction of a stress response in the vaginal epithelium (Vaneechoutte, 2017; Linhares et al., 2019). Doerflinger et al. discovered that $L$. iners, but not $L$. crispatus, significantly upregulated the pattern-recognition receptor signaling pathway in human primary vaginal epithelial cells and increased the mRNA expression of tumor necrosis factor, indicating that the vaginal microbiome regulates the host immune response species-specifically (Doerflinger et al., 2014). It has been suggested that, in response to stress, $L$. iners can activate the toll-like receptor signaling pathway in vaginal epithelial cells, increase heat shock protein 70 expression, and inhibit autophagy, which would destroy the homeostasis between vaginal epithelial cells and reduce the ability of these cells to recognize and respond to potential pathogens (Doerflinger et al., 2014; Feng et al., 2015). Conversely, many compounds involved in the antimicrobial defense of vaginal epithelial cells, such as neutrophil gelatinase-associated lipocalin, calprotectin, and hyaluronan, were also preferentially induced by L. iners (Leizer et al., 2018). These findings support the fact that $L$. iners can fight non-physiological threats, and maintain and promote the recovery to a healthier state, as well as exhibit proinflammatory qualities and act less like a commensal microbe under different conditions (Levine et al., 2011).

\section{CONCLUSIONS}

In conclusion, $L$. iners is a unique and intriguing Lactobacillus species with extraordinary characteristics. Its small genome and concurrent nutrient dependency are conducive to its high adaptation to both the low and the high $\mathrm{pH}$ vaginal environment, as well as both BV-positive and BV-negative conditions. Therefore, L. iners is often classified as a transitional species that colonizes the vagina after an ecological disturbance. However, whether L. iners is beneficial or pathogenic for the host's microbiome remains controversial. Most researchers are inclined to believe that $L$. iners offers limited protection against vaginal colonization by pathogens and may contribute to the onset and maintenance of vaginal dysbiosis. L. iners may also be a risk factor for sexually transmitted infections and adverse pregnancy outcomes. A greater understanding of the roles of $L$. iners in health and diseases in individuals of different races and ethnicities is warranted. In addition, further studies are required to clarify the role of $L$. iners in vaginal mucosal immune regulation, and to further clarify whether it can be used as a novel biomarker to detect the existence or prognosis of vaginal inflammation and guide subsequent clinical treatment.

\section{AUTHOR CONTRIBUTIONS}

NZ, RG, JW, WZ, and ZL discussed the contents, wrote, reviewed and edited the manuscript. All authors contributed to the article and approved the submitted version.

\section{FUNDING}

This present work was funded by the grants of the National Natural Science Foundation of China (81771724, 31700800, 81790631), the Taishan Scholar Foundation of Shandong Province (tsqn202103119), the Nutrition and Care of Maternal \& Child Research Fund Project of Guangzhou Biostime Institute of Nutrition \& Care (2019BINCMCF045), the National S\&T Major Project of China (2018YFC2000500), and the Foundation of China's State Key Laboratory for Diagnosis and Treatment of Infectious Diseases. 


\section{REFERENCES}

Aagaard, K., Riehle, K., Ma, J., Segata, N., Mistretta, T. A., Coarfa, C., et al. (2012). A Metagenomic Approach to Characterization of the Vaginal Microbiome Signature in Pregnancy. PloS One 7 (6), e36466. doi: 10.1371/ journal.pone. 0036466

Alonzo Martinez, M. C., Cazorla, E., Canovas, E., Martinez-Blanch, J. F., Chenoll, E., Climent, E., et al. (2021). Study of the Vaginal Microbiota in Healthy Women of Reproductive Age. Microorganisms 9 (5):1069. doi: 10.3390/ microorganisms 9051069

Aslam, S., Sayeed Saraf, V., Saleem, S., Saeed, S., Javed, S., Junjua, M., et al. (2020). Lactobacillus Species Signature in Association With Term and Preterm Births From Low-Income Group of Pakistan. J. Matern. Fetal. Neonatal. Med. 1-10. doi: 10.1080/14767058.2020.1810660

Basavaprabhu, H. N., Sonu, K. S., and Prabha, R. (2020). Mechanistic Insights Into the Action of Probiotics Against Bacterial Vaginosis and its Mediated Preterm Birth: An Overview. Microb. Pathog. 141, 104029. doi: 10.1016/ j.micpath.2020.104029

Bautista, C. T., Wurapa, E., Sateren, W. B., Morris, S., Hollingsworth, B., and Sanchez, J. L. (2016). Bacterial Vaginosis: A Synthesis of the Literature on Etiology, Prevalence, Risk Factors, and Relationship With Chlamydia and Gonorrhea Infections. Mil. Med. Res. 3, 4. doi: 10.1186/s40779-016-0074-5

Bayigga, L., Kateete, D. P., Anderson, D. J., Sekikubo, M., and Nakanjako, D. (2019). Diversity of Vaginal Microbiota in Sub-Saharan Africa and its Effects on HIV Transmission and Prevention. Am. J. Obstet. Gynecol. 220 (2), 155166. doi: 10.1016/j.ajog.2018.10.014

Beghini, J., Linhares, I. M., Giraldo, P. C., Ledger, W. J., and Witkin, S. S. (2015). Differential Expression of Lactic Acid Isomers, Extracellular Matrix Metalloproteinase Inducer, and Matrix Metalloproteinase-8 in Vaginal Fluid From Women With Vaginal Disorders. BJOG 122 (12), 1580-1585. doi: 10.1111/1471-0528.13072

Blostein, F., Gelaye, B., Sanchez, S. E., Williams, M. A., and Foxman, B. (2020). Vaginal Microbiome Diversity and Preterm Birth: Results of a Nested CaseControl Study in Peru. Ann. Epidemiol. 41, 28-34. doi: 10.1016/ j.annepidem.2019.11.004

Borgdorff, H., Armstrong, S. D., Tytgat, H. L., Xia, D., Ndayisaba, G. F., Wastling, J. M., et al. (2016). Unique Insights in the Cervicovaginal Lactobacillus Iners and L. Crispatus Proteomes and Their Associations With Microbiota Dysbiosis. PloS One 11 (3), e0150767. doi: 10.1371/journal.pone.0150767

Bradshaw, C. S., Morton, A. N., Hocking, J., Garland, S. M., Morris, M. B., Moss, L. M., et al. (2006). High Recurrence Rates of Bacterial Vaginosis Over the Course of 12 Months After Oral Metronidazole Therapy and Factors Associated With Recurrence. J. Infect. Dis. 193 (11), 1478-1486. doi: 10.1086/503780

Callahan, B. J., DiGiulio, D. B., Goltsman, D. S. A., Sun, C. L., Costello, E. K., Jeganathan, P., et al. (2017). Replication and Refinement of a Vaginal Microbial Signature of Preterm Birth in Two Racially Distinct Cohorts of US Women. Proc. Natl. Acad. Sci. U.S.A. 114 (37), 9966-9971. doi: 10.1073/ pnas. 1705899114

Campisciano, G., Florian, F., D’Eustacchio, A., Stankovic, D., Ricci, G., De Seta, F., et al. (2017). Subclinical Alteration of the Cervical-Vaginal Microbiome in Women With Idiopathic Infertility. J. Cell Physiol. 232 (7), 1681-1688. doi: $10.1002 /$ jcp. 25806

Campisciano, G., Iebba, V., Zito, G., Luppi, S., Martinelli, M., Fischer, L., et al. (2020). Lactobacillus Iners and Gasseri, Prevotella Bivia and HPV Belong to the Microbiological Signature Negatively Affecting Human Reproduction. Microorganisms 9 (1):39. doi: 10.3390/microorganisms 9010039

Castro, J., Henriques, A., Machado, A., Henriques, M., Jefferson, K. K., and Cerca, N. (2013). Reciprocal Interference Between Lactobacillus Spp. And Gardnerella Vaginalis on Initial Adherence to Epithelial Cells. Int. J. Med. Sci. 10 (9), $1193-$ 1198. doi: 10.7150/ijms.6304

Chaban, B., Links, M. G., Jayaprakash, T. P., Wagner, E. C., Bourque, D. K., Lohn, Z., et al. (2014). Characterization of the Vaginal Microbiota of Healthy Canadian Women Through the Menstrual Cycle. Microbiome 2, 23. doi: 10.1186/2049-2618-2-23

Chang, D. H., Shin, J., Rhee, M. S., Park, K. R., Cho, B. K., Lee, S. K., et al. (2020). Vaginal Microbiota Profiles of Native Korean Women and Associations With High-Risk Pregnancy. J. Microbiol. Biotechnol. 30 (2), 248-258. doi: 10.4014/ jmb.1908.08016
Chee, W. J. Y., Chew, S. Y., and Than, L. T. L. (2020). Vaginal Microbiota and the Potential of Lactobacillus Derivatives in Maintaining Vaginal Health. Microb. Cell Fact. 19 (1), 203. doi: 10.1186/s12934-020-01464-4

Chen, X., Lu, Y., Chen, T., and Li, R. (2021). The Female Vaginal Microbiome in Health and Bacterial Vaginosis. Front. Cell Infect. Microbiol. 11, 631972. doi: $10.3389 /$ fcimb.2021.631972

Chen, Y., Qiu, X., Wang, W., Li, D., Wu, A., Hong, Z., et al. (2020). Human Papillomavirus Infection and Cervical Intraepithelial Neoplasia Progression are Associated With Increased Vaginal Microbiome Diversity in a Chinese Cohort. BMC Infect. Dis. 20 (1), 629. doi: 10.1186/s12879-020-05324-9

Chen, H., Wang, L., Zhao, L., Luo, L., Min, S., Wen, Y., et al. (2021). Alterations of Vaginal Microbiota in Women With Infertility and Chlamydia Trachomatis Infection. Front. Cell Infect. Microbiol. 11, 698840. doi: 10.3389/ fcimb.2021.698840

Collins, S. L., McMillan, A., Seney, S., van der Veer, C., Kort, R., Sumarah, M. W., et al. (2018). Promising Prebiotic Candidate Established by Evaluation of Lactitol, Lactulose, Raffinose, and Oligofructose for Maintenance of a Lactobacillus-Dominated Vaginal Microbiota. Appl. Environ. Microbiol. 84 (5), e02200-e02217. doi: 10.1128/AEM.02200-17

Costerton, J. W., Stewart, P. S., and Greenberg, E. P. (1999). Bacterial Biofilms: A Common Cause of Persistent Infections. Science 284 (5418), 1318-1322. doi: $10.1126 /$ science. 284.5418 .1318

De Backer, E., Verhelst, R., Verstraelen, H., Alqumber, M. A., Burton, J. P., Tagg, J. R., et al. (2007). Quantitative Determination by Real-Time PCR of Four Vaginal Lactobacillus Species, Gardnerella Vaginalis and Atopobium Vaginae Indicates an Inverse Relationship Between L. Gasseri and L. Iners. BMC Microbiol. 7, 115. doi: 10.1186/1471-2180-7-115

De Seta, F., Campisciano, G., Zanotta, N., Ricci, G., and Comar, M. (2019). The Vaginal Community State Types Microbiome-Immune Network as Key Factor for Bacterial Vaginosis and Aerobic Vaginitis. Front. Microbiol. 10, 2451. doi: 10.3389/fmicb.2019.02451

Doerflinger, S. Y., Throop, A. L., and Herbst-Kralovetz, M. M. (2014). Bacteria in the Vaginal Microbiome Alter the Innate Immune Response and Barrier Properties of the Human Vaginal Epithelia in a Species-Specific Manner. J. Infect. Dis. 209 (12), 1989-1999. doi: 10.1093/infdis/jiu004

Eastment, M. C., and McClelland, R. S. (2018). Vaginal Microbiota and Susceptibility to HIV. AIDS 32 (6), 687-698. doi: 10.1097/ QAD.0000000000001768

Elovitz, M. A., Gajer, P., Riis, V., Brown, A. G., Humphrys, M. S., Holm, J. B., et al. (2019). Cervicovaginal Microbiota and Local Immune Response Modulate the Risk of Spontaneous Preterm Delivery. Nat. Commun. 10 (1), 1305. doi: 10.1038/s41467-019-09285-9

Falconi-McCahill, A. (2019). Bacterial Vaginosis: A Clinical Update With a Focus on Complementary and Alternative Therapies. J. Midwifery Womens Health 64 (5), 578-591. doi: 10.1111/jmwh.13013

Falsen, E., Pascual, C., Sjoden, B., Ohlen, M., and Collins, M. D. (1999). Phenotypic and Phylogenetic Characterization of a Novel Lactobacillus Species From Human Sources: Description of Lactobacillus Iners Sp. Nov. Int. J. Syst. Bacteriol. 49 Pt 1, 217-221. doi: 10.1099/00207713-49-1-217

Fanchin, R., Harmas, A., Benaoudia, F., Lundkvist, U., Olivennes, F., and Frydman, R. (1998). Microbial Flora of the Cervix Assessed at the Time of Embryo Transfer Adversely Affects In Vitro Fertilization Outcome. Fertil. Steril. 70 (5), 866-870. doi: 10.1016/s0015-0282(98)00277-5

Felten, A., Barreau, C., Bizet, C., Lagrange, P. H., and Philippon, A. (1999). Lactobacillus Species Identification, $\mathrm{H} 2 \mathrm{O} 2$ Production, and Antibiotic Resistance and Correlation With Human Clinical Status. J. Clin. Microbiol. 37 (3), 729-733. doi: 10.1128/JCM.37.3.729-733.1999

Feng, Y., Yao, Z., and Klionsky, D. J. (2015). How to Control Self-Digestion: Transcriptional, Post-Transcriptional, and Post-Translational Regulation of Autophagy. Trends Cell Biol. 25 (6), 354-363. doi: 10.1016/j.tcb.2015.02.002

Ferris, M. J., Norori, J., Zozaya-Hinchliffe, M., and Martin, D. H. (2007). Cultivation-Independent Analysis of Changes in Bacterial Vaginosis Flora Following Metronidazole Treatment. J. Clin. Microbiol. 45 (3), 1016-1018. doi: 10.1128/JCM.02085-06

Fettweis, J. M., Brooks, J. P., Serrano, M. G., Sheth, N. U., Girerd, P. H., Edwards, D. J., et al. (2014). Differences in Vaginal Microbiome in African American Women Versus Women of European Ancestry. Microbiol. (Reading) $160(\mathrm{Pt}$ 10), 2272-2282. doi: 10.1099/mic.0.081034-0 
Fettweis, J. M., Serrano, M. G., Brooks, J. P., Edwards, D. J., Girerd, P. H., Parikh, H. I., et al. (2019). The Vaginal Microbiome and Preterm Birth. Nat. Med. 25 (6), 1012-1021. doi: 10.1038/s41591-019-0450-2

France, M. T., Mendes-Soares, H., and Forney, L. J. (2016). Genomic Comparisons of Lactobacillus Crispatus and Lactobacillus Iners Reveal Potential Ecological Drivers of Community Composition in the Vagina. Appl. Environ. Microbiol. 82 (24), 7063-7073. doi: 10.1128/AEM.02385-16

Fredricks, D. N., Fiedler, T. L., and Marrazzo, J. M. (2005). Molecular Identification of Bacteria Associated With Bacterial Vaginosis. N. Engl. J. Med. 353 (18), 1899-1911. doi: 10.1056/NEJMoa043802

Gabbianelli, R., Scotti, R., Ammendola, S., Petrarca, P., Nicolini, L., and Battistoni, A. (2011). Role of ZnuABC and ZinT in Escherichia Coli O157:H7 Zinc Acquisition and Interaction With Epithelial Cells. BMC Microbiol. 11, 36. doi: 10.1186/1471-2180-11-36

Gajer, P., Brotman, R. M., Bai, G., Sakamoto, J., Schutte, U. M., Zhong, X., et al. (2012). Temporal Dynamics of the Human Vaginal Microbiota. Sci. Transl. Med. 4 (132), 132ra152. doi: 10.1126/scitranslmed.3003605

Godovalov, A. P., Danielyan, T. Y., and Karpunina, T. I. (2019). [Characteristics of Lactobacteria Strains, Having Diagnostic Significance in Gynecological Practice.]. Klin. Lab. Diagn. 64 (2), 111-116. doi: 10.18821/0869-2084-201964-2-111-116

Gondwe, T., Ness, R., Totten, P. A., Astete, S., Tang, G., Gold, M. A., et al. (2020). Novel Bacterial Vaginosis-Associated Organisms Mediate the Relationship Between Vaginal Douching and Pelvic Inflammatory Disease. Sex. Transm. Infect. 96 (6), 439-444. doi: 10.1136/sextrans-2019-054191

Goodfellow, L., Verwijs, M. C., Care, A., Sharp, A., Ivandic, J., Poljak, B., et al. (2021). Vaginal Bacterial Load in the Second Trimester is Associated With Early Preterm Birth Recurrence: A Nested Case-Control Study. BJOG. doi: 10.1111/1471-0528.16816(inpress

Gottschick, C., Deng, Z. L., Vital, M., Masur, C., Abels, C., Pieper, D. H., et al. (2017). Treatment of Biofilms in Bacterial Vaginosis by an Amphoteric Tenside Pessary-Clinical Study and Microbiota Analysis. Microbiome 5 (1), 119. doi: 10.1186/s40168-017-0326-y

Guerra, B., Ghi, T., Quarta, S., Morselli-Labate, A. M., Lazzarotto, T., Pilu, G., et al. (2006). Pregnancy Outcome After Early Detection of Bacterial Vaginosis. Eur. J. Obstet. Gynecol. Reprod. Biol. 128 (1-2), 40-45. doi: 10.1016/ j.ejogrb.2005.12.024

Gustin, A. T., Thurman, A. R., Chandra, N., Schifanella, L., Alcaide, M., Fichorova, R., et al. (2021). Recurrent Bacterial Vaginosis Following Metronidazole Treatment is Associated With Microbiota Richness at Diagnosis. Am. J. Obstet. Gynecol. doi: 10.1016/j.ajog.2021.09.018(inpress

Hall-Stoodley, L., Stoodley, P., Kathju, S., Hoiby, N., Moser, C., Costerton, J. W., et al. (2012). Towards Diagnostic Guidelines for Biofilm-Associated Infections. FEMS Immunol. Med. Microbiol. 65 (2), 127-145. doi: 10.1111/j.1574695X.2012.00968.X

Hardy, L., Cerca, N., Jespers, V., Vaneechoutte, M., and Crucitti, T. (2017). Bacterial Biofilms in the Vagina. Res. Microbiol. 168 (9-10), 865-874. doi: 10.1016/j.resmic.2017.02.001

Hoang, T., Toler, E., DeLong, K., Mafunda, N. A., Bloom, S. M., Zierden, H. C., et al. (2020). The Cervicovaginal Mucus Barrier to HIV-1 is Diminished in Bacterial Vaginosis. PloS Pathog. 16 (1), e1008236. doi: 10.1371/ journal.ppat.1008236

Human Microbiome Project, C. (2012). Structure, Function and Diversity of the Healthy Human Microbiome. Nature 486 (7402), 207-214. doi: 10.1038/ nature11234

Hummelen, R., Fernandes, A. D., Macklaim, J. M., Dickson, R. J., Changalucha, J., Gloor, G. B., et al. (2010). Deep Sequencing of the Vaginal Microbiota of Women With HIV. PloS One 5 (8), e12078. doi: 10.1371/journal.pone.0012078

Hyman, R. W., Fukushima, M., Jiang, H., Fung, E., Rand, L., Johnson, B., et al. (2014). Diversity of the Vaginal Microbiome Correlates With Preterm Birth. Reprod. Sci. 21 (1), 32-40. doi: 10.1177/1933719113488838

Jakobsson, T., and Forsum, U. (2007). Lactobacillus Iners: A Marker of Changes in the Vaginal Flora? J. Clin. Microbiol. 45 (9), 3145. doi: 10.1128/JCM.00558-07

Jang, S. J., Lee, K., Kwon, B., You, H. J., and Ko, G. (2019). Vaginal Lactobacilli Inhibit Growth and Hyphae Formation of Candida Albicans. Sci. Rep. 9 (1), 8121. doi: 10.1038/s41598-019-44579-4

Jespers, V., Menten, J., Smet, H., Poradosu, S., Abdellati, S., Verhelst, R., et al. (2012). Quantification of Bacterial Species of the Vaginal Microbiome in
Different Groups of Women, Using Nucleic Acid Amplification Tests. BMC Microbiol. 12, 83. doi: 10.1186/1471-2180-12-83

Juliana, N. C. A., Peters, R. P. H., Al-Nasiry, S., Budding, A. E., Morre, S. A., and Ambrosino, E. (2021). Composition of the Vaginal Microbiota During Pregnancy in Women Living in Sub-Saharan Africa: A PRISMA-Compliant Review. BMC Pregnancy Childbirth 21 (1), 596. doi: 10.1186/s12884-02104072-1

Kim, H., Kim, T., Kang, J., Kim, Y., and Kim, H. (2020). Is Lactobacillus GramPositive? A Case Study of Lactobacillus Iners. Microorganisms 8 (7):969. doi: 10.3390/microorganisms8070969

Kindinger, L. M., Bennett, P. R., Lee, Y. S., Marchesi, J. R., Smith, A., Cacciatore, S., et al. (2017). The Interaction Between Vaginal Microbiota, Cervical Length, and Vaginal Progesterone Treatment for Preterm Birth Risk. Microbiome 5 (1):6. doi: 10.1186/s40168-016-0223-9

Klebanoff, M. A., Schwebke, J. R., Zhang, J., Nansel, T. R., Yu, K. F., and Andrews, W. W. (2004). Vulvovaginal Symptoms in Women With Bacterial Vaginosis. Obstet. Gynecol. 104 (2), 267-272. doi: 10.1097/01.AOG.0000134783.98382.b0

Koedooder, R., Singer, M., Schoenmakers, S., Savelkoul, P. H. M., Morre, S. A., de Jonge, J. D., et al. (2019). The Vaginal Microbiome as a Predictor for Outcome of In Vitro Fertilization With or Without Intracytoplasmic Sperm Injection: A Prospective Study. Hum. Reprod. 34 (6), 1042-1054. doi: 10.1093/humrep/dez065

Kosti, I., Lyalina, S., Pollard, K. S., Butte, A. J., and Sirota, M. (2020). MetaAnalysis of Vaginal Microbiome Data Provides New Insights Into Preterm Birth. Front. Microbiol. 11, 476. doi: 10.3389/fmicb.2020.00476

Kumar, S., Kumari, N., Talukdar, D., Kothidar, A., Sarkar, M., Mehta, O., et al. (2021). The Vaginal Microbial Signatures of Preterm Birth Delivery in Indian Women. Front. Cell Infect. Microbiol. 11, 622474. doi: 10.3389/fcimb.2021.622474

Kwak, W., Han, Y. H., Seol, D., Kim, H., Ahn, H., Jeong, M., et al. (2020). Complete Genome of Lactobacillus Iners KY Using Flongle Provides Insight Into the Genetic Background of Optimal Adaption to Vaginal Econiche. Front. Microbiol. 11, 1048. doi: 10.3389/fmicb.2020.01048

Kyrgiou, M., Mitra, A., and Moscicki, A. B. (2017). Does the Vaginal Microbiota Play a Role in the Development of Cervical Cancer? Transl. Res. 179, 168-182. doi: 10.1016/j.trsl.2016.07.004

Lambert, J. A., John, S., Sobel, J. D., and Akins, R. A. (2013). Longitudinal Analysis of Vaginal Microbiome Dynamics in Women With Recurrent Bacterial Vaginosis: Recognition of the Conversion Process. PloS One 8 (12), e82599. doi: 10.1371/journal.pone.0082599

Lebeer, S., Vanderleyden, J., and De Keersmaecker, S. C. (2008). Genes and Molecules of Lactobacilli Supporting Probiotic Action. Microbiol. Mol. Biol. Rev. 72 (4), 728-764. doi: 10.1128/MMBR.00017-08 Table of Contents.

Lee, J. E., Lee, S., Lee, H., Song, Y. M., Lee, K., Han, M. J., et al. (2013). Association of the Vaginal Microbiota With Human Papillomavirus Infection in a Korean Twin Cohort. PloS One 8 (5), e63514. doi: 10.1371/journal.pone.0063514

Lee, S., Oh, K. Y., Hong, H., Jin, C. H., Shim, E., Kim, S. H., et al. (2020). Community State Types of Vaginal Microbiota and Four Types of Abnormal Vaginal Microbiota in Pregnant Korean Women. Front. Public Health 8 , 507024. doi: 10.3389/fpubh.2020.507024

Lehtoranta, L., Hibberd, A. A., Reimari, J., Junnila, J., Yeung, N., Maukonen, J., et al. (2020). Recovery of Vaginal Microbiota After Standard Treatment for Bacterial Vaginosis Infection: An Observational Study. Microorganisms 8 (6):875. doi: 10.3390/microorganisms 8060875

Leizer, J., Nasioudis, D., Forney, L. J., Schneider, G. M., Gliniewicz, K., Boester, A., et al. (2018). Properties of Epithelial Cells and Vaginal Secretions in Pregnant Women When Lactobacillus Crispatus or Lactobacillus Iners Dominate the Vaginal Microbiome. Reprod. Sci. 25 (6), 854-860. doi: 10.1177/ 1933719117698583

Levine, B., Mizushima, N., and Virgin, H. W. (2011). Autophagy in Immunity and Inflammation. Nature 469 (7330), 323-335. doi: 10.1038/nature09782

Li, W., and Ma, Z. S. (2020). Dominance Network Analysis of the Healthy Human Vaginal Microbiome Not Dominated by Lactobacillus Species. Comput. Struct. Biotechnol. J. 18, 3447-3456. doi: 10.1016/j.csbj.2020.10.033

Linhares, I. M., Sisti, G., Minis, E., de Freitas, G. B., Moron, A. F., and Witkin, S. S. (2019). Contribution of Epithelial Cells to Defense Mechanisms in the Human Vagina. Curr. Infect. Dis. Rep. 21 (9), 30. doi: 10.1007/s11908-019-0686-5

Linhares, I. M., Summers, P. R., Larsen, B., Giraldo, P. C., and Witkin, S. S. (2011). Contemporary Perspectives on Vaginal $\mathrm{pH}$ and Lactobacilli. Am. J. Obstet. Gynecol. 204 (2), 120.e121-125. doi: 10.1016/j.ajog.2010.07.010 
Liu, Z., Zhang, Z., Qiu, L., Zhang, F., Xu, X., Wei, H., et al. (2017). Characterization and Bioactivities of the Exopolysaccharide From a Probiotic Strain of Lactobacillus Plantarum WLPL04. J. Dairy Sci. 100 (9), 6895-6905. doi: 10.3168/jds.2016-11944

Machado, D., Castro, J., Palmeira-de-Oliveira, A., Martinez-de-Oliveira, J., and Cerca, N. (2015). Bacterial Vaginosis Biofilms: Challenges to Current Therapies and Emerging Solutions. Front. Microbiol. 6, 1528. doi: 10.3389/fmicb.2015.01528

Macklaim, J. M., Fernandes, A. D., Di Bella, J. M., Hammond, J. A., Reid, G., and Gloor, G. B. (2013). Comparative Meta-RNA-Seq of the Vaginal Microbiota and Differential Expression by Lactobacillus Iners in Health and Dysbiosis. Microbiome 1 (1):12. doi: 10.1186/2049-2618-1-12

Macklaim, J. M., Gloor, G. B., Anukam, K. C., Cribby, S., and Reid, G. (2011). At the Crossroads of Vaginal Health and Disease, the Genome Sequence of Lactobacillus Iners AB-1. Proc. Natl. Acad. Sci. U.S.A. 108 Suppl 1, 46884695. doi: 10.1073/pnas. 1000086107

Mane, A., Khan, I., and Thakar, M. (2020). Characterisation of Colonisation Properties of Vaginal Lactobacilli From Healthy Indian Women: Implications for Identification of Potential Probiotic Candidates. Indian J. Med. Microbiol. 38 (3 \& 4), 440-443. doi: 10.4103/ijmm.IJMM_20_108

Mayer, B. T., Srinivasan, S., Fiedler, T. L., Marrazzo, J. M., Fredricks, D. N., and Schiffer, J. T. (2015). Rapid and Profound Shifts in the Vaginal Microbiota Following Antibiotic Treatment for Bacterial Vaginosis. J. Infect. Dis. 212 (5), 793-802. doi: 10.1093/infdis/jiv079

McKloud, E., Delaney, C., Sherry, L., Kean, R., Williams, S., Metcalfe, R., et al. (2021). Recurrent Vulvovaginal Candidiasis: A Dynamic Interkingdom Biofilm Disease of Candida and Lactobacillus. mSystems 6 (4), e0062221. doi: 10.1128/ mSystems.00622-21

McMillan, A., Macklaim, J. M., Burton, J. P., and Reid, G. (2013). Adhesion of Lactobacillus Iners AB-1 to Human Fibronectin: A Key Mediator for Persistence in the Vagina? Reprod. Sci. 20 (7), 791-796. doi: 10.1177/1933719112466306

Mehta, S. D., Donovan, B., Weber, K. M., Cohen, M., Ravel, J., Gajer, P., et al. (2015). The Vaginal Microbiota Over an 8- to 10-Year Period in a Cohort of HIV-Infected and HIV-Uninfected Women. PloS One 10 (2), e0116894. doi: 10.1371/journal.pone.0116894

Mehta, S. D., Nannini, D. R., Otieno, F., Green, S. J., Agingu, W., Landay, A., et al. (2020). Host Genetic Factors Associated With Vaginal Microbiome Composition in Kenyan Women. mSystems 5 (4), e00502-e00520. doi: 10.1128/mSystems.00502-20

Miller-Ensminger, T., Garretto, A., Brenner, J., Thomas-White, K., Zambom, A., Wolfe, A. J., et al. (2018). Bacteriophages of the Urinary Microbiome. J. Bacteriol. 200 (7), e00738-e00717. doi: 10.1128/JB.00738-17

Mls, J., Stranik, J., and Kacerovsky, M. (2019). Lactobacillus Iners-Dominated Vaginal Microbiota in Pregnancy. Ceska Gynekol. 84 (6), 463-467.

Moore, D. E., Soules, M. R., Klein, N. A., Fujimoto, V. Y., Agnew, K. J., and Eschenbach, D. A. (2000). Bacteria in the Transfer Catheter Tip Influence the Live-Birth Rate After In Vitro Fertilization. Fertil. Steril. 74 (6), 1118-1124. doi: 10.1016/s0015-0282(00)01624-1

Morris, J. J., Lenski, R. E., and Zinser, E. R. (2012). The Black Queen Hypothesis: Evolution of Dependencies Through Adaptive Gene Loss. mBio 3 (2), e00036e00012. doi: 10.1128/mBio.00036-12

Moumne, O., Hampe, M. E., Montoya-Williams, D., Carson, T. L., Neu, J., Francois, M., et al. (2021). Implications of the Vaginal Microbiome and Potential Restorative Strategies on Maternal Health: A Narrative Review. J. Perinat. Med. 49 (4), 402-411. doi: 10.1515/jpm-2020-0367

Muzny, C. A., Blanchard, E., Taylor, C. M., Aaron, K. J., Talluri, R., Griswold, M. E., et al. (2018). Identification of Key Bacteria Involved in the Induction of Incident Bacterial Vaginosis: A Prospective Study. J. Infect. Dis. 218 (6), 966978. doi: 10.1093/infdis/jiy243

Muzny, C. A., Taylor, C. M., Swords, W. E., Tamhane, A., Chattopadhyay, D., Cerca, N., et al. (2019). An Updated Conceptual Model on the Pathogenesis of Bacterial Vaginosis. J. Infect. Dis. 220 (9), 1399-1405. doi: 10.1093/infdis/jiz342

Nelson, D. B., Shin, H., Wu, J., and Dominguez-Bello, M. G. (2016). The Gestational Vaginal Microbiome and Spontaneous Preterm Birth Among Nulliparous African American Women. Am. J. Perinatol. 33 (9), 887-893. doi: 10.1055/s-0036-1581057

Nilsen, T., Swedek, I., Lagenaur, L. A., and Parks, T. P. (2020). Novel Selective Inhibition of Lactobacillus Iners by Lactobacillus-Derived Bacteriocins. Appl. Environ. Microbiol. 86 (20), e01594-e01520. doi: 10.1128/AEM.01594-20
Norenhag, J., Du, J., Olovsson, M., Verstraelen, H., Engstrand, L., and Brusselaers, N. (2020). The Vaginal Microbiota, Human Papillomavirus and Cervical Dysplasia: A Systematic Review and Network Meta-Analysis. BJOG 127 (2), 171-180. doi: 10.1111/1471-0528.15854

O'Hanlon, D. E., Moench, T. R., and Cone, R. A. (2011). In Vaginal Fluid, Bacteria Associated With Bacterial Vaginosis can be Suppressed With Lactic Acid But Not Hydrogen Peroxide. BMC Infect. Dis. 11, 200. doi: 10.1186/1471-2334-11-200

Oh, H. Y., Kim, B. S., Seo, S. S., Kong, J. S., Lee, J. K., Park, S. Y., et al. (2015). The Association of Uterine Cervical Microbiota With an Increased Risk for Cervical Intraepithelial Neoplasia in Korea. Clin. Microbiol. Infect. 21 (7), 674.e671-679. doi: $10.1016 /$ j.cmi.2015.02.026

Ojala, T., Kankainen, M., Castro, J., Cerca, N., Edelman, S., WesterlundWikstrom, B., et al. (2014). Comparative Genomics of Lactobacillus Crispatus Suggests Novel Mechanisms for the Competitive Exclusion of Gardnerella Vaginalis. BMC Genomics 15, 1070. doi: 10.1186/1471-2164-151070

Osset, J., Bartolome, R. M., Garcia, E., and Andreu, A. (2001). Assessment of the Capacity of Lactobacillus to Inhibit the Growth of Uropathogens and Block Their Adhesion to Vaginal Epithelial Cells. J. Infect. Dis. 183 (3), 485-491. doi: $10.1086 / 318070$

Park, S. E., Jiang, S., and Wessels, M. R. (2012). CsrRS and Environmental pH Regulate Group B Streptococcus Adherence to Human Epithelial Cells and Extracellular Matrix. Infect. Immun. 80 (11), 3975-3984. doi: 10.1128/ IAI.00699-12

Park, S., Oh, D., Heo, H., Lee, G., Kim, S. M., Ansari, A., et al. (2021). Prediction of Preterm Birth Based on Machine Learning Using Bacterial Risk Score in Cervicovaginal Fluid. Am. J. Reprod. Immunol. 86 (3), e13435. doi: 10.1111/ aji.13435

Payne, M. S., Newnham, J. P., Doherty, D. A., Furfaro, L. L., Pendal, N. L., Loh, D. E., et al. (2021). A Specific Bacterial DNA Signature in the Vagina of Australian Women in Midpregnancy Predicts High Risk of Spontaneous Preterm Birth (the Predict1000 Study). Am. J. Obstet. Gynecol. 224 (2), 206 e201-206 e223. doi: 10.1016/j.ajog.2020.08.034

Peelen, M. J., Luef, B. M., Lamont, R. F., de Milliano, I., Jensen, J. S., Limpens, J., et al. (2019). The Influence of the Vaginal Microbiota on Preterm Birth: A Systematic Review and Recommendations for a Minimum Dataset for Future Research. Placenta 79, 30-39. doi: 10.1016/j.placenta.2019.03.011

Petricevic, L., Domig, K. J., Nierscher, F. J., Sandhofer, M. J., Fidesser, M., Krondorfer, I., et al. (2014). Characterisation of the Vaginal Lactobacillus Microbiota Associated With Preterm Delivery. Sci. Rep. 4, 5136. doi: 10.1038/ srep05136

Petrova, M. I., Lievens, E., Malik, S., Imholz, N., and Lebeer, S. (2015) Lactobacillus Species as Biomarkers and Agents That can Promote Various Aspects of Vaginal Health. Front. Physiol. 6, 81. doi: 10.3389/fphys.2015.00081

Petrova, M. I., Reid, G., Vaneechoutte, M., and Lebeer, S. (2017). Lactobacillus Iners: Friend or Foe? Trends Microbiol. 25 (3), 182-191. doi: 10.1016/ j.tim.2016.11.007

Pino, A., Bartolo, E., Caggia, C., Cianci, A., and Randazzo, C. L. (2019). Detection of Vaginal Lactobacilli as Probiotic Candidates. Sci. Rep. 9 (1), 3355. doi: 10.1038/s41598-019-40304-3

Pleckaityte, M. (2019). Cholesterol-Dependent Cytolysins Produced by Vaginal Bacteria: Certainties and Controversies. Front. Cell Infect. Microbiol. 9, 452. doi: $10.3389 /$ fcimb.2019.00452

Ponomarova, O., Gabrielli, N., Sevin, D. C., Mulleder, M., Zirngibl, K., Bulyha, K., et al. (2017). Yeast Creates a Niche for Symbiotic Lactic Acid Bacteria Through Nitrogen Overflow. Cell Syst. 5 (4), 345-357.e346. doi: 10.1016/ j.cels.2017.09.002

Ragaliauskas, T., Pleckaityte, M., Jankunec, M., Labanauskas, L., Baranauskiene, L., and Valincius, G. (2019). Inerolysin and Vaginolysin, the Cytolysins Implicated in Vaginal Dysbiosis, Differently Impair Molecular Integrity of Phospholipid Membranes. Sci. Rep. 9 (1), 10606. doi: 10.1038/s41598-019-47043-5

Rampersaud, R., Planet, P. J., Randis, T. M., Kulkarni, R., Aguilar, J. L., Lehrer, R. I., et al. (2011). Inerolysin, a Cholesterol-Dependent Cytolysin Produced by Lactobacillus Iners. J. Bacteriol. 193 (5), 1034-1041. doi: 10.1128/JB.00694-10

Ravel, J., Brotman, R. M., Gajer, P., Ma, B., Nandy, M., Fadrosh, D. W., et al. (2013). Daily Temporal Dynamics of Vaginal Microbiota Before, During and After Episodes of Bacterial Vaginosis. Microbiome 1 (1):29. doi: 10.1186/20492618-1-29 
Ravel, J., Gajer, P., Abdo, Z., Schneider, G. M., Koenig, S. S., McCulle, S. L., et al. (2011). Vaginal Microbiome of Reproductive-Age Women. Proc. Natl. Acad. Sci. U.S.A. 108 Suppl 1, 4680-4687. doi: 10.1073/pnas.1002611107

Redelinghuys, M. J., Geldenhuys, J., Jung, H., and Kock, M. M. (2020). Bacterial Vaginosis: Current Diagnostic Avenues and Future Opportunities. Front. Cell Infect. Microbiol. 10, 354. doi: 10.3389/fcimb.2020.00354

Reimers, L. L., Mehta, S. D., Massad, L. S., Burk, R. D., Xie, X., Ravel, J., et al. (2016). The Cervicovaginal Microbiota and Its Associations With Human Papillomavirus Detection in HIV-Infected and HIV-Uninfected Women. J. Infect. Dis. 214 (9), 1361-1369. doi: 10.1093/infdis/jiw374

Rosca, A. S., Castro, J., and Cerca, N. (2020). Evaluation of Different Culture Media to Support In Vitro Growth and Biofilm Formation of Bacterial Vaginosis-Associated Anaerobes. PeerJ 8, e9917. doi: 10.7717/peerj.9917

Rose, W. A.2nd, McGowin, C. L., Spagnuolo, R. A., Eaves-Pyles, T. D., Popov, V. L., and Pyles, R. B. (2012). Commensal Bacteria Modulate Innate Immune Responses of Vaginal Epithelial Cell Multilayer Cultures. PloS One 7 (3), e32728. doi: 10.1371/journal.pone.0032728

Santiago, G. L., Tency, I., Verstraelen, H., Verhelst, R., Trog, M., Temmerman, M., et al. (2012). Longitudinal qPCR Study of the Dynamics of L. Crispatus, L. Iners, A. Vaginae, (Sialidase Positive) G. Vaginalis and P. Bivia in the Vagina. PloS One 7 (9), e45281. doi: 10.1371/journal.pone.0045281

Sarmento, S. G. P., Moron, A. F., Forney, L. J., Hatanaka, A. R., Carvalho, F. H. C., Franca, M. S., et al. (2021). An Exploratory Study of Associations With Spontaneous Preterm Birth in Primigravid Pregnant Women With a Normal Cervical Length. J. Matern. Fetal. Neonatal. Med. 1-6. doi: 10.1080/ 14767058.2021.1879786

Saunders, S., Bocking, A., Challis, J., and Reid, G. (2007). Effect of Lactobacillus Challenge on Gardnerella Vaginalis Biofilms. Colloids Surf. B. Biointerfaces 55 (2), 138-142. doi: 10.1016/j.colsurfb.2006.11.040

Shipitsyna, E., Roos, A., Datcu, R., Hallen, A., Fredlund, H., Jensen, J. S., et al. (2013). Composition of the Vaginal Microbiota in Women of Reproductive Age-Sensitive and Specific Molecular Diagnosis of Bacterial Vaginosis Is Possible? PloS One 8 (4), e60670. doi: 10.1371/journal.pone.0060670

Spear, G. T., Gilbert, D., Landay, A. L., Zariffard, R., French, A. L., Patel, P., et al. (2011). Pyrosequencing of the Genital Microbiotas of HIV-Seropositive and -Seronegative Women Reveals Lactobacillus Iners as the Predominant Lactobacillus Species. Appl. Environ. Microbiol. 77 (1), 378-381. doi: 10.1128/AEM.00973-10

Srinivasan, S., and Fredricks, D. N. (2008). The Human Vaginal Bacterial Biota and Bacterial Vaginosis. Interdiscip Perspect. Infect. Dis. 2008, 750479. doi: $10.1155 / 2008 / 750479$

Srinivasan, S., Hoffman, N. G., Morgan, M. T., Matsen, F. A., Fiedler, T. L., Hall, R. W., et al. (2012). Bacterial Communities in Women With Bacterial Vaginosis: High Resolution Phylogenetic Analyses Reveal Relationships of Microbiota to Clinical Criteria. PloS One 7 (6), e37818. doi: 10.1371/journal.pone.0037818

Srinivasan, S., Liu, C., Mitchell, C. M., Fiedler, T. L., Thomas, K. K., Agnew, K. J., et al. (2010). Temporal Variability of Human Vaginal Bacteria and Relationship With Bacterial Vaginosis. PloS One 5 (4), e10197. doi: 10.1371/ journal.pone.0010197

Stout, M. J., Zhou, Y., Wylie, K. M., Tarr, P. I., Macones, G. A., and Tuuli, M. G. (2017). Early Pregnancy Vaginal Microbiome Trends and Preterm Birth. Am. J. Obstet. Gynecol. 217 (3), 356 e351-356 e318. doi: 10.1016/j.ajog.2017.05.030

Subramaniam, A., Kumar, R., Cliver, S. P., Zhi, D., Szychowski, J. M., Abramovici, A., et al. (2016). Vaginal Microbiota in Pregnancy: Evaluation Based on Vaginal Flora, Birth Outcome, and Race. Am. J. Perinatol. 33 (4), 401-408. doi: 10.1055/s-0035-1565919

Tabatabaei, N., Eren, A. M., Barreiro, L. B., Yotova, V., Dumaine, A., Allard, C., et al. (2019). Vaginal Microbiome in Early Pregnancy and Subsequent Risk of Spontaneous Preterm Birth: A Case-Control Study. BJOG 126 (3), 349-358. doi: 10.1111/1471-0528.15299

Tachedjian, G., Aldunate, M., Bradshaw, C. S., and Cone, R. A. (2017). The Role of Lactic Acid Production by Probiotic Lactobacillus Species in Vaginal Health. Res. Microbiol. 168 (9-10), 782-792. doi: 10.1016/j.resmic.2017.04.001

Taff, H. T., Mitchell, K. F., Edward, J. A., and Andes, D. R. (2013). Mechanisms of Candida Biofilm Drug Resistance. Future Microbiol. 8 (10), 1325-1337. doi: $10.2217 / \mathrm{fmb} .13 .101$

Tortelli, B. A., Lewis, W. G., Allsworth, J. E., Member-Meneh, N., Foster, L. R., Reno, H. E., et al. (2020). Associations Between the Vaginal Microbiome and
Candida Colonization in Women of Reproductive Age. Am. J. Obstet. Gynecol. 222 (5), 471 e471-471 e479. doi: 10.1016/j.ajog.2019.10.008

Vaneechoutte, M. (2017). Lactobacillus Iners, the Unusual Suspect. Res. Microbiol. 168 (9-10), 826-836. doi: 10.1016/j.resmic.2017.09.003

van Houdt, R., Ma, B., Bruisten, S. M., Speksnijder, A., Ravel, J., and de Vries, H. J. C. (2018). Lactobacillus Iners-Dominated Vaginal Microbiota is Associated With Increased Susceptibility to Chlamydia Trachomatis Infection in Dutch Women: A Case-Control Study. Sex. Transm. Infect. 94 (2), 117-123. doi: 10.1136/sextrans-2017-053133

Verstraelen, H., Verhelst, R., Claeys, G., De Backer, E., Temmerman, M., and Vaneechoutte, M. (2009). Longitudinal Analysis of the Vaginal Microflora in Pregnancy Suggests That L. Crispatus Promotes the Stability of the Normal Vaginal Microflora and That L. Gasseri and/or L. Iners are More Conducive to the Occurrence of Abnormal Vaginal Microflora. BMC Microbiol. 9, 116. doi: 10.1186/1471-2180-9-116

Wang, Z., Zhang, L., Zhao, M., Wang, Y., Bai, H., Wang, Y., et al. (2021). Deep Neural Networks Offer Morphologic Classification and Diagnosis of Bacterial Vaginosis. J. Clin. Microbiol. 59 (2), e02236-e02220. doi: 10.1128/JCM.02236-20

Wells, J. S., Chandler, R., Dunn, A., and Brewster, G. (2020). The Vaginal Microbiome in U.S. Black Women: A Systematic Review. J. Womens Health (Larchmt) 29 (3), 362-375. doi: 10.1089/jwh.2019.7717

Witkin, S. S. (2015). The Vaginal Microbiome, Vaginal Anti-Microbial Defence Mechanisms and the Clinical Challenge of Reducing Infection-Related Preterm Birth. BJOG 122 (2), 213-218. doi: 10.1111/1471-0528.13115

Witkin, S. S., Mendes-Soares, H., Linhares, I. M., Jayaram, A., Ledger, W. J., and Forney, L. J. (2013). Influence of Vaginal Bacteria and D- and L-Lactic Acid Isomers on Vaginal Extracellular Matrix Metalloproteinase Inducer: Implications for Protection Against Upper Genital Tract Infections. mBio 4 (4), e00460-e00413. doi: 10.1128/mBio.00460-13

Witkin, S. S., Moron, A. F., Linhares, I. M., and Forney, L. J. (2021). Influence of Lactobacillus Crispatus, Lactobacillus Iners and Gardnerella Vaginalis on Bacterial Vaginal Composition in Pregnant Women. Arch. Gynecol. Obstet. 304 (2), 395-400. doi: 10.1007/s00404-021-05978-z

Yoshimura, K., Ogawa, M., and Saito, M. (2020). In Vitro Characteristics of Intravaginal Lactobacilli; Why is L. Iners Detected in Abnormal Vaginal Microbial Flora? Arch. Gynecol. Obstet. 302 (3), 671-677. doi: 10.1007/s00404-020-05634-y

Zarate, G., and Nader-Macias, M. E. (2006). Influence of Probiotic Vaginal Lactobacilli on In Vitro Adhesion of Urogenital Pathogens to Vaginal Epithelial Cells. Lett. Appl. Microbiol. 43 (2), 174-180. doi: 10.1111/j.1472-765X.2006.01934.x

Zheng, N., Guo, R., Yao, Y., Jin, M., Cheng, Y., and Ling, Z. (2019). Lactobacillus Iners Is Associated With Vaginal Dysbiosis in Healthy Pregnant Women: A Preliminary Study. BioMed. Res. Int. 2019, 6079734. doi: 10.1155/2019/ 6079734

Zhou, X., Hansmann, M. A., Davis, C. C., Suzuki, H., Brown, C. J., Schutte, U., et al. (2010). The Vaginal Bacterial Communities of Japanese Women Resemble Those of Women in Other Racial Groups. FEMS Immunol. Med. Microbiol. 58 (2), 169-181. doi: 10.1111/j.1574-695X.2009.00618.x

Zozaya-Hinchliffe, M., Lillis, R., Martin, D. H., and Ferris, M. J. (2010). Quantitative PCR Assessments of Bacterial Species in Women With and Without Bacterial Vaginosis. J. Clin. Microbiol. 48 (5), 1812-1819. doi: 10.1128/JCM.00851-09

Conflict of Interest: The authors declare that the research was conducted in the absence of any commercial or financial relationships that could be construed as a potential conflict of interest.

Publisher's Note: All claims expressed in this article are solely those of the authors and do not necessarily represent those of their affiliated organizations, or those of the publisher, the editors and the reviewers. Any product that may be evaluated in this article, or claim that may be made by its manufacturer, is not guaranteed or endorsed by the publisher.

Copyright (c) 2021 Zheng, Guo, Wang, Zhou and Ling. This is an open-access article distributed under the terms of the Creative Commons Attribution License (CC BY). The use, distribution or reproduction in other forums is permitted, provided the original author(s) and the copyright owner(s) are credited and that the original publication in this journal is cited, in accordance with accepted academic practice. No use, distribution or reproduction is permitted which does not comply with these terms. 